\title{
REFUSAL OF ASSENT - A HIDDEN ELEMENT OF CONSTITUTIONAL HISTORY IN NEW ZEALAND
}

\author{
Dr John E Martin*
}

This article explores Britain's influence historically over legislation passed in the New Zealand Parliament. It suggests that Britain's role was substantial, particularly in the 19th century. For nearly a century, from 1854 until New Zealand adopted the Statute of Westminster in 1947, all New Zealand laws (of which nearly one hundred laws were reserved) were sent to Britain for scrutiny. In thirteen instances laws were considered sufficiently problematic that Britain either disallowed legislation already assented to by the Governor or, alternatively, refused assent to or withheld assent from reserved legislation. Other legislation was amended on Britain's instructions.

The exercise of royal assent was an important ingredient in New Zealand's development and an integral part of its movement from colony to independent nation.

\section{INTRODUCTION}

For nearly a century from 1854, when New Zealand gained representative government, all legislation passed by the New Zealand Parliament - both reserved and assented to by the Governor/Governor-General - was sent to Britain for scrutiny. ${ }^{1}$ It was not until 1947, when the country adopted the Statute of Westminster 1931, that this practice halted.

In most cases Britain agreed to the legislation without comment or qualification, but over the period nearly a hundred Bills were reserved and a number of measures received serious attention. ${ }^{2}$

* Parliamentary Historian, Parliament Buildings.

1 Thanks to Alex McBean, Michelle Schulz and Pleasance Purser of the Parliamentary Library for their assistance with this paper. I am indebted to David McGee for his clarification of the process of assent and his very helpful comments.

2 See Alpheus Todd Parliamentary Government in the British Colonies (2nd ed, Longmans, Green, London, 1894) at ch 5; Arthur Berriedale Keith Responsible Government in the Dominions (Clarendon Press, Oxford, 1928) at 749ff; J Hight and HD Bamford The Constitutional History and Law of New Zealand 
Britain refused assent to some legislation. The process of gaining royal assent was neither smooth nor free of controversy. It reveals in an interesting fashion the shifting constitutional relationship between the colony and Britain and provides significant benchmarks in the process of New Zealand gaining full autonomy in its lawmaking.

\section{A Constitution Act 1852}

Section 56 of the Constitution Act 1852 spelled out the Governor's powers. (From this point on, reference will usually be to "the Governor" as the discussion is largely confined to the pre-1917 period.) The Governor had the discretion, subject to the Constitution Act and his instructions, to assent to, refuse assent to, or reserve legislation for Britain's assent. ${ }^{3}$ The Governor could also amend legislation.

Sections 57-59 spelled out Britain's role. Britain was to issue instructions to the Governor to guide him in the exercise of the powers of assent and reservation. The Governor was to send copies of all legislation to Britain. Britain had two years to consider whether to disallow legislation assented to by the Governor. Britain also had two years to decide whether to assent to legislation reserved by the Governor. Reserved legislation did not have the force of law until Britain had assented to it.

Other sections of the Constitution Act indicated areas of lawmaking which would be problematic for New Zealand. Section 53 gave the colonial legislature competence to make laws for the peace, order, and good government of New Zealand, provided that such laws were not repugnant to the law of England. "Repugnancy" was an elusive concept relating to conflict between colonial and English law. The extent of conflict and whether it was fundamental was hard to determine. The decisions of a South Australian judge in the early 1860s, which reflected a very broad notion of repugnancy and questioned the South Australian State's legislative role as a whole, led to the clarifying (Imperial) Colonial Laws Validity Act $1865 .{ }^{4}$ This defined repugnancy and limited it to specific conflicts of a colonial law with an imperial Act which itself extended to that colony.

(Whitcombe and Tombs Ltd, Christchurch, 1914) at 385-8; CC Aikman "Parliament" in JL Robson (ed), New Zealand: The Development of its Laws and Constitution (2nd ed, Stevens, London, 1967); RO McGechan "Status and Legislative Inability" in JC Beaglehole (ed) New Zealand and the Statute of Westminster (Victoria University College, Wellington, 1944); DB Swinfen Imperial Control of Colonial Legislation, 1813-1865: A Study of British Policy Towards Colonial Legislative Powers (Oxford University Press, Oxford, 1970) at ch 3.

3 We should not disregard the vetting of legislation passed by provincial councils. Under the Constitution Act 1852 the Governor could refuse assent to such legislation. Some 266 provincial Bills were "disallowed" while many others were amended or repealed by General Assembly legislation, see (1882) I AJHR A-14; Todd, above $\mathrm{n} 2$, at $428-429$.

4 Swinfen, above $\mathrm{n} 2$, at ch 11 . 
Implicit also in s 53 was a limitation of New Zealand's lawmaking to domestic concerns. ${ }^{5}$ Legislation which went beyond or was "excessive" to New Zealand's legislative powers would be ultra vires. Moreover, s 61 specifically restricted New Zealand's legislative powers concerning customs duties affecting the British army or navy or British treaties.

By s 71 native policy was effectively retained by the Crown, delegated to the Governor who became responsible for maintaining the laws, customs and usages of Māori. Section 65 stipulated that the Governor must reserve legislation altering the Governor's salary or the extent of funds designated for "native purposes" ( $£ 7,000$ in the schedule to the Act).

In conclusion, the Constitution Act set out constraints on New Zealand's capacity to legislate unfettered. Britain had a continued imperial responsibility for New Zealand's affairs, conflict could arise with English law ("repugnancy"), and legislation could go beyond or be "excessive" to New Zealand's legislative powers. These constraints were further clarified by Britain's instructions to the Governor.

\section{B The Governor's Instructions}

The Constitution Act 1852 suggested that the Governor would be guided by instructions from Britain. Sir George Grey, Governor of New Zealand at the time of the adoption of the Constitution Act, did not appear to have received any specific instructions prior to his departure from New Zealand in 1853. In any case Parliament did not begin its lawmaking until 1854. RH Wynyard stood in as Administrator in lieu of a Governor at that time but during these first two sessions of Parliament in 1854 it emerged that there was uncertainty as to whether New Zealand had been formally granted responsible government.

When Thomas Gore Browne became Governor in 1855 Britain confirmed that it had endowed New Zealand with responsible government. Britain also issued specific instructions that the Governor should reserve any Bills infringing the sovereign's prerogative as well as those concerning currency, divorce, parliamentary grants to the Governor, along with sundry other concerns. ${ }^{6}$ In addition the Governor was instructed to reserve all Bills of an "extraordinary or unusual nature"

5 Extra-territoriality was somewhat elastic in nature. In the 19th century New Zealand felt constrained by this provision. By the early 20th century Solicitor-General John W Salmond was able to argue that there was nothing to prevent New Zealand from extra-territorial legislation "for the peace, order, and good government" of the country as long as it was not repugnant to English law. "The Limitations of Colonial Legislative Power" (1917) 33 LQR 117 at 130.

6 "Commission of Governor of New Zealand with accompanying Royal instructions" (1856) Legislative Council Votes and Proceedings, appendices. Other matters concerned freedom of religion, lotteries and private Bills, together with technical inconsistencies in Bills and Bills enacted for less than a year. Bills should not contain provisions of Bills previously refused assent. Inclusion of private Bills was soon considered anachronistic and was removed from the instructions, Swinfen, above n 2, at 86-87. 
together with those requiring Britain's "special consideration", particularly those affecting British subjects outside the colony and British trade and shipping.

Britain issued new instructions in 1861 upon the appointment of Sir George Grey as Governor once again. ${ }^{7}$ They spelled out a range of reasons for reserving Bills, extending to Bills concerning differential duties and those inconsistent with British treaties or interfering with the army or navy. If a Bill, otherwise likely to be reserved, urgently needed to come into operation, the Governor could assent to it meanwhile. From 1873 the Governor could assent to urgent legislation unless it was specifically repugnant to British law or inconsistent with British treaties.

Such instructions were renewed when Sir George Bowen replaced Grey in 1867, with the list now comprising divorce, parliamentary grants to the Governor, currency, differential duties, treaties, army and navy, together with infringements of the sovereign's prerogative on British subjects outside the colony, on trade and on shipping. ${ }^{8}$ The same list was reiterated in 1873 and 1879.

\section{Procedure in Practice}

All legislation, including Bills already assented to by the Governor, was sent to Britain accompanied by explanatory notes for consideration. The Colonial Office, led by its legal adviser, handled the process. It referred legislation on to the appropriate government department depending on the nature of the issue - the Foreign Office where treaties were involved, Treasury for banking matters and the Board of Trade for shipping, for example. ${ }^{9}$ The Secretary of State for the Colonies made decisions on the legislation, which were forwarded to his or her Majesty-in-Council for the formal "signification of his/her Majesty's pleasure".

Having received Britain's decisions on the legislation, the Governor issued proclamations (usually published in the New Zealand Gazette) in aggregate for all unreserved Bills and separately for reserved Bills. ${ }^{10}$ Any disallowed Acts were also dealt with by proclamation. When assent was withheld or refused there would usually be no formal notification in the Gazette.

As this outline of the process suggests, Britain could block legislation, either by disallowance of the enacted and assented legislation or by not giving assent to reserved Bills. ${ }^{11}$ Almost always laws to which the Governor had already assented would be "left to their operation". It was a draconian

7 (1868) AJHR A-1 at 3-7.

8 (1868) AJHR A-5 at 3-6; (1875) I AJHR A-3 at 1-5; (1879) I AJHR session II A-1 at 1-6.

9 Swinfen, above $\mathrm{n} 2$, at $\operatorname{ch} 2$ and 3.

10 The Interpretation Act 1858 specifically prescribed that all Acts which did not state when they took effect and which were reserved would come into operation on the day that the Governor, by speech, message or proclamation, signified that assent had been given.

11 See Todd, above n 2, at ch 5, especially at 158 table; "Colonial Acts - Royal assent" (1894) Great Britain Parliamentary Papers (GBPP) HL196. 
step to disallow legislation that had already been implemented. Disallowance rendered the entire Act null and void.

Refusing assent was less severe than disallowance, in that the legislation had been reserved by the Governor, but it was a heavy-handed intervention that Britain would rather avoid. Withholding assent was a more effective, flexible and negotiable way of dealing with problematic legislation. Britain could note difficulties with the legislation and New Zealand's legislators (if they wished) could redraft it, make amendments or allow it to lapse. In other cases Britain would give assent but express the hope that New Zealand would amend the legislation in the future. In such circumstances New Zealand frequently passed new legislation that would be assented to.

In the period during which Britain had such powers (1854-1947) it blocked important legislation on a number of occasions. The power of royal assent was used to prevent thirteen pieces of legislation from 1856 to 1910.

In two instances Britain disallowed Acts already assented to by the Governor and on the statute book (the Waste Lands Act 1856 and the Indemnity Act 1866).

On five occasions Britain specifically notified New Zealand that it would refuse assent to Bills (the Native Territorial Rights Bill 1858, Picton Railway Bill 1861, Governor's Salary Bill 1867, Extradition Bill 1873, and the Administration Bill 1878).

On another six occasions Britain held its decision in abeyance (withheld assent) for two years and the Bills became void (the Native Council Bill 1860, Provincial Compulsory Land Taking Bill 1863, Colonial Reciprocity Bill 1870, Confederation and Annexation Bill 1883, Asiatic Restriction Bill 1896 and the Shipping and Seamen Amendment Bill 1910).

\section{Recent Views}

This summary of the powers of assent and their exercise suggests that a detailed scrutiny of the fate of legislation from 1854 until 1947 is in order. From the perspective of today, with New Zealand having full lawmaking powers, it is easy to neglect these arrangements of the past that gave Britain an active role. McLean's recent history, The Governors, does not delve into such constitutional dimensions of the role of Governors, devoting more attention to their symbolic and ceremonial roles and their various personalities and impact on the country. ${ }^{12}$

In 1986, when New Zealand put its constitutional legal framework in order, the historical anomaly of royal assent to legislation was largely removed from the Constitution Act. The majority view in the Officials Committee on Constitutional Reform considering such issues was that explicit

12 Gavin McLean The Governors: New Zealand's Governors and Governors-General (Otago University Press, Otago, 2006) at 72 and 291. 
reference to the possibility of withholding or refusing assent should be dropped. ${ }^{13}$ A minority on the committee felt, contrarily, that there was not a case for dropping explicit reference to this possibility because the reserve powers (which still existed) necessarily could not be clearly defined.

Geoffrey Palmer, Minister of Justice, and the Government accepted the majority conclusions of the Committee. During the parliamentary debate on the Constitution Bill, Palmer dismissed the objections of Doug Graham and Doug Kidd to the lack of reference to refusal of assent. He was adamant that the Governor-General must assent to Bills and that this was a longstanding convention. ${ }^{14}$ Section 16 of the Constitution Act 1986 as a result simply said that legislation "shall become law when the Sovereign or the Governor-General assents to it". Palmer was to conclude in Public Law in New Zealand that "there is no known instance where the Governor-General has refused assent to a New Zealand Bill". ${ }^{15}$ But the Governor-General's powers of assent do remain in place even if silently. Joseph states that "a Bill becomes law when it receives the royal assent and the power to grant the assent implies also the power to withhold assent."16

First we need to establish precisely what we are referring to. Are we talking about the person of the Governor or Governor-General, or are we talking about the constitutional relationship between Britain and New Zealand? If the former, it is true that the Governor has not personally refused assent to any Bills even though, as the sovereign's representative, he had the power to do so under the Constitution Act. (On one occasion in 1877 the Governor was urged to do so but he refused.)

If we are talking about the broader constitutional relationship, then the Governor was simply an intermediary in the process of giving or refusing assent. To restrict the discussion to the person of the Governor means turning a blind eye to the underlying issue - that of the colonial relationship in New Zealand's lawmaking. ${ }^{17}$

A misleading impression of the issue of royal assent is compounded by statements, when apparently related to New Zealand, that no British monarch has refused assent to legislation since

13 Officials Committee Constitutional Reform (First and second reports, Department of Justice, February 1986) at 39-41.

14 (3 December 1986) 476 NZPD 5854-5855 and 5860-5861.

15 Mai Chen and Sir Geoffrey Palmer Public Law in New Zealand (Oxford University Press, Oxford, 1993) at 163.

16 Phillip A Joseph Constitutional and Administrative Law in New Zealand (3rd ed, Thomson Brookers, Wellington, 2007) at 713.

17 Todd's classic text Parliamentary Government in the British Colonies, above n 2, draws attention to royal assent in his assertion of the continued role of the British sovereign in the colonies. A modern work on New Zealand's legal history makes some reference to royal assent but more to affirm the extent of autonomy of New Zealand as a self-governing colony, see Peter Spiller, Jeremy Finn and Richard Boast A New Zealand Legal History (2nd ed, Brookers, Wellington, 2001) at 61-65. 
1707 in the reign of Queen Anne. ${ }^{18}$ This should not be taken to suggest that New Zealand legislation has never been blocked by Britain.

\section{LEGISLATIVE BOUNDARIES}

We now look at New Zealand's legislation over the decades following the establishment of parliamentary government in 1854 . The first decade or so of legislative activity by the New Zealand Parliament was accompanied by searching scrutiny of its lawmaking by Britain, not only on the vexed matters of legislation affecting Māori and land but also concerning "excessive" powers of Parliament that transgressed the Constitution Act or affected Imperial interests. With the transfer of responsibility for Māori affairs to the government by the mid 1860s one cause for problematic legislation was removed.

\section{A Delegating to Provinces}

No sooner had New Zealand begun legislating than it ran up against Britain's scrutiny. There had been some warning of this following the first rather unsatisfactory sessions of 1854 in which little legislation got passed. The reserved Provincial Waste Lands Bill 1854 was closely looked at. Britain pointed out that the General Assembly could not ignore the restrictions of the Constitution Act 1852 on delegating powers to provinces and altering provincial constitutions. ${ }^{19}$

It was vital for the General Assembly to sort out its relationship with the provinces and the extent to which powers could be delegated. The provincial councils had got a head start, having been able to assemble before the General Assembly because Governor Grey refused to summon the latter. This allowed the provinces to consolidate their position and pass legislation that would prove problematic. Britain also made it clear that certain constitutional changes were not possible - such as making the Legislative Council elective and authorising provincial Superintendents, rather than the Governor, to dissolve provincial councils. These and other measures could not be assented to if they appeared in legislation, Britain warned. ${ }^{20}$

In the session of 1856 Parliament got down to the serious business of legislating, now that a stable government had been established. Edward Stafford had formed a ministry that would last until 1861. Recently arrived Governor Gore Browne reserved the Provincial Councils Powers Bill but assented to the Waste Lands Bill. While Britain assented to the Provincial Councils Powers Bill the Waste Lands Act ran into problems. It empowered provinces to make land laws for the sale of

18 Joseph, above n 16, at 713, elsewhere, at 111-113, he distinguishes between the Governor and the sovereign and acknowledges that the latter did indeed on occasion disallow legislation.

19 (1858) AJHR A-1 at 4. It appears that assent was given although this cannot be traced in the New Zealand Gazette. The Waste Lands Act 1856 stated that this 1854 legislation was extant, confirmed by (1882) I AJHR A-13.

20 (1854-5) GBPP $38 \mathrm{HC} 160$ at 39-40. 
Crown waste lands and to sell land. Britain disallowed the legislation because it exceeded the powers of the legislature. Provinces were unable to pass such legislation under s 19 of the Constitution Act 1852 and there was doubt about land revenue going to the provinces. ${ }^{21}$ The following session (two years later) Parliament passed the new Waste Lands Bill 1858. This gave administrative powers over land, but not legislative powers, to provinces. The legislation, which was reserved, was eventually assented to after the New Zealand Government argued that it was appropriate. $^{22}$

\section{B Legislating for Māori}

The New Zealand Parliament also had a warning shot fired across its bows concerning legislation affecting Māori. The Native Reserves Bill 1856 originally gave administrative responsibility to the Governor, but the Government controversially brought in a new cl 18 stipulating that the Governor should act only on the advice and with the consent of the Executive Council. $^{23}$ Some Legislative Councillors thought that this legislation transgressed upon the Governor's responsibility for Māori affairs and on the Constitution Act and thus it should be reserved. They petitioned Gore Browne to this end. Minister for Native Affairs CW Richmond denied that this was the case and advised the Governor to assent to the Bill. Gore Browne delayed for some time but eventually did so on condition that his correspondence concerning the Bill and the petition be sent to Britain with the Act.

Britain's reply was that the Governor should be able to work with the legislation even if legally the clause opposed the agreed-to principle. The Governor's assent would not be over-ruled. But evidently the measure caused consternation, for a report within the British Government on the legislation advised disallowance on the grounds that Britain should not surrender control over Māori affairs, at least until New Zealand paid for most of its defence. Britain should stand resolutely against such advances of the New Zealand Parliament.

It became evident during the session of 1856 that the House of Representatives considered control over Māori affairs to go hand in hand with the responsible government that Britain had just confirmed. A fragile compromise with Gore Browne was reached meanwhile. ${ }^{24}$ A new Native

21 (1858) AJHR A-1 at 3-4; "Governor, proclamation disallowing Waste Lands Act 1856, 3 June 1858" (4 June 1858) New Zealand Gazette at 82. A number of other Acts giving powers to the provinces were closely scrutinised as a result of this section of the Constitution Act. 580; (6 July 1858) 1856-1858 NZPD 585.

24 W David McIntyre (ed) The Journal of Henry Sewell, 1853-7 (Whitcoulls, Christchurch, 1980) vol 1, "Introduction" at 111-114. See also WP Morrell British Colonial Policy in the Mid-Victorian Age (Oxford University Press, Oxford, 1969) at 213-223; BJ Dalton War and Politics in New Zealand, 1855-1870 (Sydney University Press, Sydney, 1967) at ch 2 and 3; Keith Sinclair The Origins of the Māori Wars (2nd 
Department would be placed under the "general oversight" of a minister but with final decisions reserved for the Governor. But Parliament now legislated in terms that subordinated Gore Browne through what became the "Governor in Council" phrase - a legislative wedge levering the Governor out of responsibility for Māori affairs. Britain approved of Gore Browne's assertion of his responsibility, particularly on the grounds of the maintenance in the colony of British forces paid for by Britain. Over the next two years Gore Browne found that he was not able to implement any Māori policies, especially as the Government controlled the money.

\section{The Landmark Session of 1858}

There was no session in 1857. The following year, 1858, Parliament passed a torrent of laws (a total of 80 Bills) compared with earlier sessions, a number of which set the parameters for the country's legal framework. The Government also attempted to develop its own concerted Māori policy through the Native Territorial Rights Bill, the Native District Regulations Bill and the Native Circuit Courts Bill. ${ }^{25}$ Included in this legislation was the "Governor in Council" phrase, signalling a shifting responsibility for Māori affairs.

This legislation raised fundamental constitutional questions. Minister for Native Affairs Richmond tried to establish in advance which Bills Gore Browne was prepared to approve and believed he had gained his support. ${ }^{26}$ The Bills proceeded through the House of Representatives without a great deal of discussion, but met strong opposition in the Legislative Council. The "Governor in Council" phrase in the Native Territorial Rights Bill in particular went through the Council by a single vote (in the absence of a key opponent of the measure).

Faced with this burst of legislating, Gore Browne felt the need to assert his powers. He reserved ten Bills for further consideration. He also assented to a number of other pieces of legislation which subsequently faced serious scrutiny by Britain. ${ }^{27}$

First, we look at the assented legislation of 1858. Britain was inclined to recommend disallowance of the Absent Debtors and the Absent Defendants Acts for their excessive powers, but agreed to defer the move for the maximum two year period to allow their amendment. New Zealand

ed, New Zealand University Press, Wellington, 1961) at 85-90, for the background and nature of this compromise.

25 (18 May 1858) 1856-1858 NZPD 442ff; (1860) GBPP 47 HC492; Alan Ward A Show of Justice: Racial Amalgamation in Nineteenth Century New Zealand (Auckland University Press, Auckland, 1974) at 107108; Morrell, ibid, at 225-229.

26 Gore Browne to Richmond (22 June 1858) in Guy E Scholefield (ed) The Richmond-Atkinson Papers (RE Owen, Government Printer, Wellington, 1960) vol 1 at 411; (26 May 1858) 1856-1858 NZPD 470; (5 July 1858) 1856-1858 NZPD 583.

27 (1860) AJHR A-4. 
agreed to repeal these two Acts and in 1860 (the following session - there was none in 1859) this was done.

The Militia, New Zealand Post Office and Foreign Seamen's Acts required lengthy consideration. Britain required that the first be amended; this was done by legislation in 1860. It was in the end decided to leave the second "to its operation". Shipping legislation was to prove the most enduring area of difficulty (see below). Britain insisted that the Foreign Seamen's Act be amended on threat of disallowance. The Act was repealed by an 1860 Act which included the provision Britain wanted.

Britain was also petitioned to disallow the New Provinces Act but decided to leave it to its operation on condition that it was amended. This was done by legislation in 1860 which clarified how land would be affected by the creation of a new province. Britain also deferred consideration of the Bankers' Returns Act for it to be amended. This duly occurred in 1860. Furthermore, the Interpretation Act (concerning technicalities in Parliament passing Acts) contained a problem relating to the definition of New Zealand's territory. After correspondence Britain conceded that it would leave the Act to its operation.

The Native Districts Regulations Act included a section objectionable to Britain. While reluctant to disallow the entire Act because of the "public disconvenience" and delay that would be caused, Britain insisted that New Zealand agree that all regulations issued under the problematic section were subject to the Governor's assent and should not come into operation until this had been carried out. In sum, a significant number of assented Acts of the 1858 session required amendment or other modification to their operation.

While Britain assented to eight of the ten reserved Bills of 1858 without difficulty, the Waste Lands Bill and the Native Territorial Rights Bill were not as straightforward. Britain eventually assented to the Waste Lands Bill (see above) but it considered the Native Territorial Rights Bill extremely objectionable. ${ }^{28}$ Its object was to allow colonists to purchase land directly from Māori on an individualised basis. This was inadvisable according to Britain - it would cause a revolution in land purchase and was fraught with problems. The land tax on sales would cause distrust. New Zealand would also need to rely on the British military to enforce the legislation but such a power was not given to Britain. In conclusion Britain said that it could not surrender control of Māori affairs and the military in such a manner. The Native Territorial Rights Bill was refused assent, causing anger in the colony.

28 (1860) AJHR A-4 at 27-28. Britain was unable to recommend assent. Note that (1882) I AJHR A-13 describes the legislation as disallowed. 


\section{Further Difficulties}

Parliament did not meet in 1859. When it did meet in 1860 Parliament confronted a virtually unprecedented situation. Britain, encouraged by Gore Browne and without consulting the New Zealand Government, had introduced the New Zealand Bill 1860 into the Westminster Parliament to provide for a Native Council. ${ }^{29}$ The Council was to work alongside Gore Browne, independently of the Government. The British Government justified the move in terms of the Constitution Act 1852 which placed Māori policy in the hands of the Crown, the military cost borne by Britain in supplying troops, and the instability of New Zealand governments that rendered them "not competent" to deal with the situation. The measure, although passed in the Lords, was withdrawn by the Government in the Commons after strenuous lobbying by colonists in London and a petition presented on behalf of the New Zealand Government.

In the British Parliament considerable qualms were expressed about the propriety of passing such a law without the consent of a self-governing colony. In the end the British Government accepted that it should not press ahead with a measure that concerned "important principles of colonial legislation". It believed that there were sufficient powers for the Crown under the Constitution Act to protect the interests of Māori, and if not, then the government could reconsider legislation.

Alarmed by this move, the New Zealand Government rapidly drew up its own Native Council Bill, creating an advisory Māori Council but putting it under the Government's thumb. Gore Browne reserved the Bill, while acknowledging that the measure was the best that could be obtained from the New Zealand Parliament. ${ }^{30}$ (Britain meanwhile waited for Gore Browne to be replaced by Sir George Grey before deciding what to do - see below.)

Half a dozen Bills were reserved in 1861, and two private Acts caught the eye of the British Treasury, which pointed out some issues with the legislation. ${ }^{31}$ In a most unusual step William Fox's Government itself recommended that Britain refuse to assent to the private Picton Railway Bill. ${ }^{32}$

29 (3 July 1860) Hansard's Parliamentary Debates 3rd series 159 at 1326-1329 (UK); (6 July 1860) Hansard's Parliamentary Debates 3rd series 159 at 1518-1519 (UK); (14 August 1860) Hansard's Parliamentary Debates 3rd series 160 at 1318 (UK); (17 August 1860) Hansard's Parliamentary Debates 3rd series 160 at 1459-1460; (21 August 1860) Hansard's Parliamentary Debates 3rd series 160 at 1639-1649; Dalton, above n 24, at 91-92, 118-121 and 141-142; Morrell, above n 24, at 250-255; Ward, above n 25, at 108.

30 (1862) AJHR E-2.

31 "Secretary of State for Colonies, despatch, 20 September 1862" (29 November 1862) New Zealand Gazette at 342-343; "Colonial Secretary, Acts left to their operation, 25 November 1862" (29 November 1862) New Zealand Gazette at 345.

32 (1862) AJHR A-2 at 1 and 6. 
There were deep-felt political divisions in this bizarre episode between the new Speaker David Monro, member for Picton and a supporter of Edward Stafford, and Fox. ${ }^{33}$ This Bill, facilitating a local railway, had been introduced while Stafford was still in power. Monro was a strong backer of the measure but could not be seen to be too obvious in his support.

The Bill was controversial. ${ }^{34}$ One member alleged that three members on the select committee appointed to consider it (which included Monro) had a pecuniary interest in the measure and that there had been irregularities in the committee. Monro, although Speaker, participated in a vigorous debate on the Bill while it was in Committee of the Whole. The Bill went through the House despite Fox defeating Stafford on a motion of no-confidence and forming a new ministry. On its third reading Fox warned that he would not be bound by the legislation in terms of the required loan. His final flourish was to recommend that the Governor refuse assent to the Bill. A prior provincial ordinance facilitating the railway had already been disallowed. Gore Browne reserved the Bill and Britain refused its assent. ${ }^{35}$

\section{WARRING PARTIES}

This squabble over a local railway, although important to the politics of the day, was somewhat of a distraction from more serious events with longer-term constitutional consequences. In 1860, the simmering conflict arising out of Māori resistance to land sales burst out into war in Taranaki. The tension between Gore Browne and the Government over Māori and military matters reached breaking point. The contentious matter of the Native Council legislation had not helped at all. Gore Browne's attempts to take effective charge of Māori affairs had proved fruitless and he had been drawn into war by accepting a crucial block of land at Waitara. After a year an uneasy peace emerged but the larger threat of the Waikato King movement remained.

33 See (23 August 1869) 6 NZPD 661; John E Martin The House: New Zealand's House of Representatives, 1854-2004 (Dunmore Press, Palmerston North, 2004) at 34-35, 37 and 66-67; AF Campbell, "The Speakership of the NZ House of Representatives, 1854-1912" (1952) MA thesis, Canterbury University College, at 108-119. It is possible that their antagonism began with the absence of Fox and his Wellington supporters from the House when Monro was elected Speaker. O'Rorke trenchantly criticised the move and attempted unsuccessfully to have the election postponed until they had arrived, see (3 June 1861) 1861-1863 NZPD 2.

34 (6 August 1861) 1861-1863 NZPD 262-263; (14 August 1861) 1861-1863 NZPD 289; Southern Cross (Auckland, 9 August 1861) referred to a "long and rather personal" debate; Nelson Examiner (Nelson, 18 September 1861)

35 (1862) AJHR E-2; "Colonial Secretary, regarding Picton Railway Act 1861, 5 April 1862" (7 April 1862) New Zealand Gazette at 147. Britain advised New Zealand that it would withhold assent; (1882) I AJHR A13 describes the legislation as disallowed. 


\section{A Responsibility for Māori Affairs}

The conflict between Gore Browne and the Government was to prove a turning point in Britain's relationship with its colony. As Māori and Pakeha fought in New Zealand Britain began to rethink its colonial responsibilities. ${ }^{36}$

When the New Zealand Parliament sent a resolution to Gore Browne that the challenge to Her Majesty's sovereignty posed by the King movement must be confronted, in unprecedented fashion he sent a message directly to the House, bypassing the Government. ${ }^{37}$ Gore Browne laid down his own challenge - he would not call upon British troops unless New Zealand co-operated fully. Some questioned whether he had the right to demand this. Parliament assured him of its co-operation but within the limits of the country's resources.

Immediately afterwards news arrived that Gore Browne was to be relieved by Sir George Grey. Gore Browne had struggled valiantly to deal with the mounting crisis between settlers and Māori, but Britain thought that Grey's experience in governing and in dealing with the Māori was needed.

The appointment of Grey completely changed the power relationships at work. Britain could now see no better approach than yielding discretionary power to him to do what he saw fit. Britain said that it would withhold assent from New Zealand's Native Council Bill until Grey was able to report. ${ }^{38}$ If Grey felt it was necessary he could propose a short Bill to bring the legislation into operation immediately, and this would be assented to. Grey declined to do this. He believed that a Council might be divisive and rival Parliament for the loyalty of Māori. He proposed district runanga instead of a Council. This proposal was supported by the Government, as was his statement that he would conduct Māori policy through the Government. Britain endorsed the proposals but emphasised that New Zealand should share the military costs. The Native Council Bill was never assented to and Grey, despite his declarations, assumed considerable powers over Māori affairs.

The session of 1862 again produced a number of reserved Bills, one of which was the momentous Native Lands Bill. This would introduce direct purchase of individualised Māori land with title established by a Native Land Court. Minister for Native Affairs F.D. Bell argued that both Grey and Britain approved of the move. He cited a letter to Grey that Britain would "assent to any prudent plan" along these lines. ${ }^{39}$ And, in resigned fashion, Britain did indeed assent to the Bill.

36 JRM Butler "Imperial Questions in British Politics, 1868-1880" in EA Benians, JRM Butler and CE Carrington (eds) The Cambridge History of the British Empire (Cambridge University Press, Cambridge, 1959) vol 3.

37 Dalton, above n 24, at 131 and ch 5; Southern Cross (Auckland, 28 June 1861); (25 June 1861) 1861-1863 NZPD 75.

38 (1862) AJHR E-1 section 2 at 34-36; (1862) AJHR E-1 section 3 at 1, 9; (1862) AJHR E-2 at 8-10.

39 (25 August 1862) 1861-1863 NZPD 610; (1863) AJHR A-3 at 22-23; Morrell, above n 24, at 286-287. 
Parliament had no intention of allowing the Imperial Government or Grey to dictate on this aspect of Māori policy. The colonial Government now had this responsibility.

Britain formally discharged its responsibility for Māori affairs in early $1863 .{ }^{40}$ The Secretary of State pointed out that the New Zealand government had the legislative powers and the power to grant money, even if the Governor had administrative responsibility. The British attempt in 1860 to pass legislation (the New Zealand Bill) to make the Governor's powers effective was opposed by New Zealand. Britain would now relinquish any responsibility for Māori affairs as a result of the inadequacy of the Crown's powers and the refusal of the New Zealand Government to accept them. Nonetheless, Britain had "a right to require from the colonists that their native policy ... should be just, prudent and liberal" for as long as its military forces remained. ${ }^{41}$

\section{B Repugnancy of War}

Britain remained very critical of a range of legislation and was quite prepared to continue to intervene. Two Acts of 1862 were under threat of disallowance - the Native Purposes Appropriation and Colonial Defence Force Acts. Both were amended in 1863 as a result and were assented to.

Grey began to contemplate the possibility of an invasion of the Waikato to deal with the King movement. With further conflict in Taranaki in May 1863 he and the Government agreed that the military should move south into the Waikato in July 1863. Parliament met late that year to endorse developments, and passed a range of amending and consolidating provincial land legislation that required reservation, along with crucial legislation to deal with the situation of war.

The only problematic Bill amongst those reserved was the Provincial Compulsory Land Taking Bill. ${ }^{42}$ Doubts had been expressed whether the provinces had the power to take land compulsorily for roads and other public purposes. The legislation was intended to remove these doubts and to validate previous provincial actions. Britain withheld assent from the Bill because it included Māori land. An amended Bill attempted to deal with this, but the Attorney General wanted further amendments and the Bill was discharged. With the expiry of the two-year period new legislation was required. This was introduced in 1866, minus the offending clause of 1863. The Bill was reserved and assented to.

The New Zealand Settlements Act 1863 - passed to enable confiscation of Māori land in the wake of the land wars - received extremely close scrutiny from Britain. ${ }^{43}$ The legislation had come

40 (1863) GBPP $38 \mathrm{HC} 177$ at 8-16; see also Morrell, above n 24, at ch 9; and Dalton, above n 24, at 171-173.

41

(1863) GBPP $38 \mathrm{HC} 177$ at 16.

2 (1864) AJHR A-1 at 15; (2 December 1864) 1864-1866 NZPD 62; (17 July 1866) 1864-1866 NZPD 780.

43 Morrell, above n 24, at 298-301 and 313; Dalton, above n 24, at 181-182, 188-197, 201-203 and 241-243; (1864) AJHR A-1 at 3-4; (1864) AJHR E-2 appendix at 20; (1865) AJHR A-6 at 10-19; (1865) GBPP 37 3425 at 102-103; (1866) AJHR A-1 part 2 at 21 and 52-56. 
under serious criticism in the House from James FitzGerald, who said he could not conceive that Britain would assent to the legislation and described the measure as an "enormous crime". ${ }^{44}$ In the Legislative Council Dr Pollen found it "immoral"; he hoped that Britain would step in. The New Zealand Government argued that this Act, together with its accompanying Suppression of Rebellion Act 1863, were vital pieces of legislation. Grey had given assent to the measure on the basis of the necessity for its immediate operation.

Britain wanted to disallow the Act but did not want to weaken Grey's hand. It saw the Act as too sweeping, lacking in checks and likely to promote continued hostility. The Act should be limited to two years and a commission independent of government should determine the extent of land forfeited. Rather than confiscation, Britain advocated that the Governor oversee cession of land as a condition of the pardoning of rebels.

In the House of Commons MPs talked of disallowing the Act. The Secretary of State for the Colonies defended his actions. While there were many objections to the Act, it would create a bad impression indeed to disallow the very first legislation New Zealand had passed since gaining responsibility for Māori affairs and it could create "anarchy" in the country. ${ }^{45}$ It was better to seek limits to the legislation through its amendment.

New Zealand's Attorney-General Frederick Whitaker made no bones about the Government's stance. He stated that Britain's view was subversive of the arrangement over Māori affairs. The Governor was not entitled to act independently of the Government in such matters. Meanwhile the Colonial Treasurer was in Britain negotiating a new $£ 3$ million loan. This gave Britain some purchase. It agreed to guarantee $£ 1$ million on condition that New Zealand pay more towards the cost of troops and limit the duration of the New Zealand Settlements Act to two years.

However, Grey and the Government reached deadlock over the direction of the military campaign and Britain's expectation that Grey would negotiate a less draconian form of confiscation came to nothing. With the new Government proclaiming the "self reliance" of the country, including the eventual withdrawal of British troops from New Zealand, Grey was brought to heel, and largescale confiscation took place.

The Act was amended in 1864 to meet Britain's concerns to a limited degree - its operation was to end in December 1865. But it did not establish a commission nor introduce satisfactory compensation provisions. Grey assented to the amending legislation but disallowance remained a distinct possibility. Britain continued to place faith in Grey's ability to moderate the impact of the Act. The New Zealand Government responded that Britain's stance was "fraught with consequences

44 (5 November 1863) 1861-1864 NZPD 784; (16 November 1863) 1861-1864 NZPD 872.

45 (26 April 1864) Hansard's Parliamentary Debates 3rd series 174 at 1625-1659, especially at 1647-1649. 
disastrous to the Colony of New Zealand". ${ }^{46}$ Legislation was again introduced in 1865, with the Bill at its second reading stage sent to Britain. This would make the confiscation legislation perpetual with a proviso that there would be no confiscation after December 1867. Britain refused to give an opinion until the final legislation was sent.

When it was received, Britain pointed out that the effective span of the legislation since the first legislation of 1863 would amount to four years rather than two. Compensation provisions remained unsatisfactory. But with British troops being withdrawn, Britain refrained from disallowance of the Act at that time. If circumstances changed it might still do so - and there it was left. Because the Governor had assented to the initial legislation of 1863 nothing further needed to be done. In this case disallowance would have been virtually certain had it not been for the rapidly changing shift of constitutional powers.

The land wars also resulted in Parliament passing the Indemnity Act 1865 to indemnify those involved in the conflicts; this was assented to by the Governor. Britain was not happy with its scope. When an even broader Indemnity Act was passed in 1866, also assented to by the Governor, Britain disallowed the 1866 Act. ${ }^{47}$ An amended Indemnity Bill, passed in 1867, embodied the required amendments. It was assented to.

In a rather startling sequel to this period of conflict, Governor Grey was ignominiously recalled and replaced by Sir George Bowen in 1867. By this time, despite all the previous troubles, Grey had redeemed himself in New Zealand eyes. Parliament leaped to his defence, in an act of spite aimed at the replacement Governor, and through the Governor's Salary Bill attempted to reduce Bowen's salary by $£ 1,000$. Such legislation had to be reserved under the Constitution Act 1852. Britain saw no justification in the measure and refused assent to the legislation. ${ }^{48}$

Following this Britain expressed concern with two further pieces of legislation in 1869 which attempted to deal with continued disturbances. The Disturbed Districts Act and the Arms Act Amendment Act would not be disallowed but they needed amendment. ${ }^{49}$ The former, which suspended habeas corpus and introduced other draconian powers to deal with people in areas

46 (1865) AJHR A-5A at 4.

47 "Governor, proclamation disallowing Indemnity Act 1866, 15 August 1867" (31 August 1867) New Zealand Gazette at 335; (1867) AJHR A-1 at 42-43. Both Acts had been implemented meanwhile, "Governor, proclamation, 15 August 1866" (17 August 1866) New Zealand Gazette at 325; "Governor, proclamation, 21 November 1866" (27 November 1866) New Zealand Gazette at 434.

48 (1868) AJHR A-1A at 16; "Secretary of State for Colonies, despatch, 25 January 1868" (20 April 1868) New Zealand Gazette at 180-181. Britain found it impossible to advise assent.

49 (1870) I AJHR A-1 A at 24-25; (1 September 1869) 6 NZPD 906-908. See also (1871) I AJHR A-1 A at 29, Britain decided not to disallow the New Zealand and Australian Submarine Telegraph Act 1870 even though it was strongly against the Governor giving exclusive rights to private parties to lay cables. This Act was not amended. 
affected by disturbances, expired after a year and thus was probably left to its operation. Britain regarded capital punishment for arms trading to rebels, under the Arms Act Amendment Act, as too severe. The legislation was amended in 1871 to make it clear that the penalties in the original Arms Act 1860 still applied. The Governor assented to the 1871 Bill.

By the late 1860s Britain was determined to remove all its troops from New Zealand. There developed a crisis of confidence in the British-New Zealand colonial relationship as Premier Frederick Weld's self-reliance policy proved a failure. ${ }^{50}$ Its catalyst was Britain's refusal to guarantee a large loan. Premier Stafford tried by all means possible to keep a garrison but failed. New Zealand felt that Britain was deserting it at a time when disturbances by Māori continued. In frustration there was rash talk of independence from Britain. A deputation saw the Secretary of State for the Colonies in 1869 in London, but this did not prevent the last troops leaving in early 1870. Gladstone and the British Government had determined upon reducing its expenditure and wanted New Zealand to become more self-reliant.

Following the withdrawal of British troops, New Zealand managed to extract agreement from Britain to guarantee a smaller loan. This conciliatory move on Britain's part was a crucial element in Julius Vogel being able to come forward with his public works and immigration policy of 1870 . This policy set the tone for national development into the future and would be a vehicle for eventual greater national autonomy.

The rash talk of independence in New Zealand after a difficult decade of legislative intervention by Britain was still-born but it did presage what was to come. The experience told New Zealand politicians that they would have to take a greater responsibility. Already there had been a significant reduction in the sphere within which Britain felt it necessary to intervene, with New Zealand's assumption of responsibility for Māori affairs. Other areas of colonial responsibility would eventually emerge as the bonds gradually loosened and as New Zealand's politicians developed a "colonial nationalist" streak. Vogel was a forerunner; he would be followed by Sir George Grey, John Ballance, Richard John Seddon and Sir Joseph Ward. Meanwhile a range of legislation ran the gauntlet of British scrutiny, and in particular Bills that might be repugnant or involve excessive powers. New Zealand still to a large degree accepted British intervention in its lawmaking with little complaint.

50 Morrell, above n 24, at ch 11; Butler, above n 36, at 24-26; W David McIntyre Dominion of New Zealand: Statesmen and Status 1907-1945 (New Zealand Institute of International Affairs, Wellington, 2007) at 3031; Richard Koebner and Helmut Dan Schmidt, Imperialism: The Story and Significance of a Political Word, 1840-1960 (Cambridge University Press, Cambridge, 1964) at 95-102; Michael Burgess, "Imperial Federation: Continuity and Change in British Imperial Ideas, 1869-1871" (1983) 17 NZ Journal of History; RM Dalziel The Origins of NZ Diplomacy: The Agent-General in London 1870-1905 (Victoria University Press, Wellington, 1975) at 21-22; Scholefield above n 26, at 261-264, 285-287, 295, 298 and 302-303; McIntyre, above n 24, at 319-321. 


\section{MATTERS OF REPUGNANCY AND EXCESSIVE POWERS}

The gold rushes and the flood of unregulated immigration to the country highlighted New Zealand's incapacity to deal with criminals. In 1863 the New Zealand Government drew up the Criminals Bill, modelled on Victorian State legislation, to prevent criminals coming over from Australia and in particular to the Otago goldfields. ${ }^{51}$ Otago Province had passed similar legislation in 1861 but it had been disallowed. The Government explained that the Bill was more to indicate to Britain that something needed to be done than to put it on the statute book. (The Bill accidentally failed to get through the Legislative Council because of the absence of members, but some saw it as excessive and extreme.)

Britain responded that it would not disallow such legislation if passed, because the Victorian Act had not been disallowed. Nonetheless the legislation was inadvisable. New Zealand suggested that Britain should pass legislation to prevent New Zealand becoming "a cesspool for the convict population", 52 or alternatively empower New Zealand to do so. (Another Otago Act was disallowed in 1864.) Eventually, in 1867 New Zealand passed the Introduction of Convicts Prevention Bill which was assented to. This provided substantial powers of arrest and penalties, including deportation and fines for those bringing convicts in or harbouring them while in New Zealand.

At the same time as drawing up the Criminals Bill (and for similar reasons), Parliament passed the Foreign Offenders' Apprehension Bill 1863. This built on existing British extradition legislation and dealt with offenders crossing the Tasman. The legislation enabled the apprehension of offenders and their removal from New Zealand and included minor indictable misdemeanours as well as felonies. But in correspondence with Britain the Attorney-General noted that the legislation could be regarded as ultra vires. ${ }^{53}$ It received assent nonetheless.

The following year, 1864, Supreme Court judge Johnston J in the first edition of his manual for JPs suggested the legislation could be repugnant to British legislation generally by dealing with offences committed outside New Zealand and specifically by including misdemeanours. ${ }^{54}$ The British legislation included only treason and felonies. He advised JPs to rely on the British legislation instead.

51 (7 December 1863) 1861-1963 NZPD 980-981, 1005 and 1009; (28 August 1867) 1 NZPD 306; (1864) AJHR A-1 at 18-19.

52 (1864) AJHR A-1 at 19.

53 In re Gleich (1879) 1 OB\&F (SC), at 42; see also Todd, above $\mathrm{n} 2$, at 302-303.

54 Alexander James Johnston, The New Zealand Justice of the Peace: a Treatise on the Powers, Duties and Liabilities of Magistrates, Coroners \& Peace Officers in the Colony: With a Digest of the Law of Evidence and an Appendix of Acts and Forms (M'Kenzie \& Muir, Wellington, 1864) at 288-292. The same warning was in the second and third editions, (1870) at 438-442; (1879) at 450-453. The latter had an inserted addendum that the Act had indeed been found ultra vires in the Gleich case, ibid. 
In 1867, after an intercolonial conference in Melbourne, the Australian States together with New Zealand asked Britain to extend its legislation. ${ }^{55}$ Britain was still unenthusiastic and suggested that the colonies consider their own legislation that allowed offenders to be tried both where an offence was committed and where the person was apprehended.

New Zealand remained concerned about such issues. Following doubts that the imperial Extradition Act 1870 was suitable to deal with a German bankrupt in New Zealand, the AttorneyGeneral, James Prendergast, sought Britain's advice. Britain suggested that New Zealand legislate as Canada had done. But Britain refused to assent to the resulting Extradition Bill of $1873 .{ }^{56}$ It argued that New Zealand enact new legislation more closely along the lines of the imperial legislation. The new Bill of 1874 was assented to.

In 1879 two cases heard in the New Zealand Supreme Court suggested that the Foreign Offenders' Apprehension Act 1863 was problematic and indeed ultra vires. ${ }^{57}$ In the case of a murder in the Gilbert Islands involving one Thomas Rennell, Gillies J concluded that the Act applied only within Australasia and the prisoner was discharged. He advised the Government to take action to prevent any recurrence. The second (celebrated) case involved a bankrupt, Frederick Gleich, who absconded to New Zealand from Australia and established a hotel in Wellington under an alias. The Supreme Court concluded by majority, including Johnston $\mathrm{J}$ who had previously raised the issue (Prendergast CJ, Johnston, Richmond and Williams JJ, with Gillies J dissenting), that New Zealand did not have the power to deport Gleich and he had to be released. Prendergast CJ argued that the Act was not repugnant in regard to misdemeanours but that New Zealand had no power to legislate to deport offenders. Johnston $\mathrm{J}$ commented that the question had arisen before and it was expected that Britain would legislate to deal with the matter. (Britain had prepared a Bill in 1876 but it did not get onto the statute book.)

The Government reiterated its request to Britain to extend the legislation. Following another intercolonial conference in Sydney and discussion on colonial legislation to deal with the problem, in 1881 Britain passed the Fugitive Offenders Bill. This allowed offenders in one country to be apprehended and returned to another where the offence was committed. It applied to all British possessions, and included misdemeanours subject to twelve months imprisonment with hard labour, along with treason and felonies.

55 (1867) AJHR A-1 at 54; A-1 A at 59-61; Todd, above $\mathrm{n} 2$, at 303.

56 (1873) I AJHR A-1 at 21-23; A-2 at 7-10, 17-19 and 21; (1874) I AJHR A-2A at 3-4. Britain was unable to advise assent.

57 Ex parte Rennell (1879) 1 OB\&F (SC) 72; In re Gleich (1879) 1 OB\&F (SC) 39; (1879) I AJHR session I A-3; (1880) I AJHR A-1 at 56-57; A-2 at 44; A-6; (1881) I AJHR A-2 at 8; (1882) I AJHR A-1 at 2-3 and 6-7, and A-2 at 2 and 5. (1882) I AJHR A-13 describes the Act as ultra vires. It was repealed in 1891. 
New Zealand also needed Britain's co-operation to deal with its vexed provincial system. The County of Westland Act 1867 transgressed the Constitution Act and was ultra vires, as the New Zealand Government candidly admitted. ${ }^{58}$ Britain agreed to legislate and did so in 1868 (An Act to declare the powers of the General Assembly of New Zealand to abolish any province) to give the New Zealand Parliament greater powers and to validate the Act. This introduced the legal means for the eventual abolition of all the provinces in the mid 1870s.

New Zealand laws continued to fall foul of repugnancy. Britain wanted the Privileges Act 1866, assented to by the Governor, to be amended. ${ }^{59}$ Speaker of the House of Representatives David Monro had been summoned to appear in court. This legislation, rushed through with no debate, exempted MPs from attendance in court during parliamentary sessions. Britain felt that the exemption was too broad and that the Act was not consistent with other colonies and countries. No amendment was forthcoming and Britain did not seem to press the matter. (It is possible the matter was overlooked as a result of the turmoil associated with Governor Grey's recall.)

Britain also saw problems in the British-Australasian Mail Service Act 1867, intended to further a postal service that had been agreed to at an Australasian conference. ${ }^{60}$ The scheme required Britain to contribute half of the cost and it refused to do so. While Britain did not disallow the Act clearly it would not come into operation. It was formally repealed in 1878.

Laws relating to marriage and inheritance were regarded as repugnant. In 1878 Britain refused assent to the Administration Bill because it might affect the estates of those residing outside New Zealand. ${ }^{61}$ This legislation extended the Real Estate Descent Act 1874 (that had removed the law of primogeniture) by declaring that all real property was personal property, as existed in several other British colonies. A new amended Bill of 1879 was assented to.

In 1880 Parliament passed the Deceased Wife's Sister Marriage Bill. ${ }^{62}$ Such legislation had been extremely contentious in Australian States and had been blocked on several occasions because it gave rise to incompatible legislation within the Empire. Such marriages were considered invalid in Britain. In New Zealand this measure had been long pressed as a private member's Bill. The Attorney-General's legal opinion of 1871 was that it was not necessarily repugnant, notwithstanding such a declaration in South Australia and the fact that English law on marriage was in force in New

58 WP Morrell, The Provincial System in New Zealand 1852-76 (Whitcombe and Tombs, Christchurch, 1964) at 196-197; (1868) AJHR A-1 at 10 and 12-18; (1868) AJHR A-1 A at 21; (1869) I AJHR A-1A at 1. submit the legislation for assent. See also (1880) I AJHR A-1 at 9 and 29, and A-2A at 22. 
Zealand. The Governor reserved the Bill and Britain assented to it despite its conflict with English law. Subsequently, from the first Colonial Conference of 1887 onwards both New Zealand and Australia lobbied for Britain to recognise the legitimacy of such marriages. ${ }^{63}$ Britain eventually did so in 1906, and made such marriages legal in Britain itself in 1907.

Britain continued to intervene when it thought that repugnancy was an issue. In 1900, an emerging national identity received a rebuff when Britain withheld consideration of the New Zealand Ensign Bill until new legislation was submitted to it. ${ }^{64}$ Britain pointed out that the blue ensign specified in the legislation could be used by New Zealand merchant vessels which should be flying the red ensign. The flag also conflicted with British ships flying the blue ensign by Admiralty warrant. Moreover, the reservation clause within the Bill was inappropriate. It implied that reservation was within the powers of the House of Representatives rather than in the hands of the Governor. New Zealand admitted the validity of the objections and passed new legislation in 1901 . This was assented to.

In 1912 Britain again withheld consideration of New Zealand legislation until it had been altered. The Divorce and Matrimonial Causes Amendment Act 1912 had not been reserved by the Governor but Britain regarded it as repugnant. ${ }^{65}$ The legislation deprived litigants of the right of appeal to the Privy Council. New Zealand had to pass amending legislation in 1913.

\section{THE GOVERNOR'S RESERVE POWERS UNDER SCRUTINY}

There remained important areas related to excessive powers that would come to the fore as New Zealand's legislation increasingly extended into the wider world, dominated as it was by the British Empire. While fewer Bills were reserved and fewer were seen as problematic by Britain it still took a long time for New Zealand to gain full lawmaking powers. In the 1890s the energetic reformist Liberal Government and in particular the powerful populist Premier Richard John Seddon espoused an emerging colonial nationalism that questioned the extent of the Governor's reserve powers. ${ }^{66}$

\section{A Testing the Boundaries}

In the late 1870 s the country witnessed a bizarre incident that threatened to disrupt the usually placid year-by-year progress of Bills onto the statute book. In 1877 Grey's new Government inherited a Land Bill from the previous Government which included contentious provisions to extend Canterbury pastoral licences which Grey was dead set against.

63 (1887) GBPP 56 C5091 at 113-122.

64 (1901) I AJHR A-2A.

65 See Alex Frame Salmond: Southern Jurist (Victoria University Press, Wellington, 1995) at 98; (1914) I AJHR A-1 at 15 and 33; (1914) I AJHR A-2 at 3.

66 David Hamer The New Zealand Liberals: The Years of Power, 1891-1912 (Auckland University Press, Auckland, 1988) at 52-64. 
Following his failure to have these clauses taken out (while the Bill was in the Committee of the Whole House) and the passage of the Bill into law, Grey in an extraordinary move advised Governor Normanby to refuse assent to the Bill. ${ }^{67}$ Normanby declined to comply. The advice "seemed to me so extraordinary a proceeding that $\mathrm{I}$ at once refused to veto the Bill" he said. ${ }^{68}$ Normanby pointed out that both Houses had passed the Bill. He considered Grey's move a trick on Parliament at a time when almost all its members had left Wellington at the end of the session. When Grey failed to sign his name to the form advising assent to the Land Bill Normanby in turn withheld his signature from the Appropriation Bill, threatening the future supply of money. Grey was forced to sign the form and the Land Bill was assented to.

This confrontation worsened an existing acrimonious situation between Grey and the Governor. Grey took the matter to Britain, arguing that the Governor had to accept government advice on all matters, but Britain supported Normanby's actions. The Governor's powers over legislation, independent of the New Zealand government, remained in place.

In 1883 the New Zealand Government came up against the limits of its legislative powers with the Confederation and Annexation Bill. ${ }^{69}$ This was a permissive Bill, sponsored by Sir George Grey, now a backbench MP, to sanction arrangements with Pacific Islands that might wish to confederate with or be annexed by New Zealand. At this time there was heightened colonial interest in the Pacific to which Australia and New Zealand were not immune. Queensland had occupied part of New Guinea. The Government was involved in discussions over annexation of Pacific Islands and in particular Samoa, at a time when the major powers were jostling for position in the Pacific. The legislation was reserved.

Grey was then involved in getting Samoa to petition for annexation at a time of threat of German takeover. The speculation was that the petition was an attempt to force Britain's hand in granting assent. ${ }^{70}$ If so it was not successful. Britain withheld assent from the legislation despite pleading by New Zealand's Agent-General in London. Britain refused to accept such an imperialistic move by New Zealand.

67 "Governor, Secretary of State for Colonies, and Premier, despatches and memoranda nos 8-15, regarding assent to Land Bill 1877, 10 December 1877 to 20 June 1878" (21 June 1878) New Zealand Gazette at 91220. See also (1877) I AJHR A-7; (1878) I AJHR A-1 at 3-4 and 19-27; Edmund Bohan To Be a Hero: A Biography of Sir George Grey (Harper Collins, Auckland, 1998) at 257-258; J Rutherford Sir George Grey $K C B, 1812-1898$ (Cassell, London, 1961) at 604-606; Todd, above n 2, at 664-665.

68 "Governor to Secretary of State for Colonies, regarding assent to Land Bill 1877, 10 December 1877" (21 June 1878) New Zealand Gazette at 912.

69 (1884) I AJHR session II A-3 at 16; (1908) I AJHR A-4. For New Zealand's interest in Samoa, see Raewyn Dalziel Julius Vogel: Business Politician (Auckland University Press, Auckland, 1986) at ch 12.

70 Evening Post (Wellington, 19 January 1885 and 14 March 1885). 
With the Liberal Government assuming power in 1891 a confrontation developed between it and the Governor over appointments to the Legislative Council. ${ }^{71}$ The Legislative Council, stacked by the outgoing Atkinson Government, was blocking key Liberal reformist legislation. Britain endorsed Atkinson's appointments, but when Liberal Premier Ballance sought to make his own appointments the recently arrived Governor, the Earl of Glasgow, refused to accept them.

Britain instructed Glasgow to accept the appointments and generally to follow the advice of the Government: "the Governor should, as a general rule, and when Imperial interests are not affected, accept [the government's] advice, bearing in mind that the responsibility rests with the Ministers, who are answerable to the Legislature, and, in the last resort, to the country." ${ }^{72}$ It was only in extreme and exceptional circumstances that the Governor should act contrary to the government's advice. Britain also issued Glasgow with revised instructions that contained a subtle but significant shift in emphasis. ${ }^{73}$ The previous instructions had said that the Governor could act in opposition to the advice of the government. This was replaced by a statement that the Governor should be guided by the advice of the government, but if he had "sufficient cause to dissent" he could act in opposition to the views of the government. ${ }^{74}$ In practice the shift in the Governor's role was substantial. Glasgow complained that "the range of questions in which the Governor has any discretion is reduced to a vanishing point". ${ }^{75}$ With regard to legislation, unless imperial interests were obviously affected through repugnancy, the Governor should only reserve Bills on the advice of the government. ${ }^{76}$

\section{B Excluding Asiatics}

Despite this shift Seddon, who took over the Premiership from Ballance when he died in 1893, came up against an immoveable obstacle. Britain would not countenance overtly "racist" immigration legislation. Such legislation emanating from the Australasian colonies had proved

71 (1891) I AJHR session II A-2 at 11. This endorsement was used by Premier Ballance to argue that the Governor should accept his government's advice on appointments, see (1893) I AJHR A-7A at 19; WK Jackson, The New Zealand Legislative Council: a Study of the Establishment, Failure and Abolition of an Upper House (University of Otago Press, Dunedin, 1972) at ch 12; McLean, above n 12, at ch 6.

72 (1893) I AJHR A-2 at 27.

73 "Colonial Secretary, Royal Instructions to Governor, 26 March 1892" (14 July 1892) New Zealand Gazette at 1026. (1893) I AJHR A-2 at 2.

74 The instructions were also simplified and they removed what were now regarded as inappropriate sections unsuited to a colony with responsible government. Previously the Governor had his own discretionary power in granting pardons; now this was on the advice of the government.

75 (1893) I AJHR A-1 at 18.

76 Aikman and Robson "Introduction" in Robson, above n 2, at 11-12; Aikman "Parliament" in Robson, above n 2 , at 61 . 
controversial with Britain in the past as a result of its treaty obligations. ${ }^{77}$ Victoria and New South Wales had legislated against Chinese immigration in the 1850s and early 1860s and had drawn strong protest from Britain even if the legislation was not disallowed. And then the State of Queensland passed restrictive legislation in 1876 which Britain refused to accept. Queensland's subsequent legislation of 1877 introduced a $£ 10$ poll tax instead. This was less objectionable to Britain and was assented to. In New Zealand agitation amongst gold-miners, trade unions and others against Chinese increased during the 1870 s. There was clamour for measures similar to those in Australia. $^{78}$

In 1879 the New Zealand Government introduced legislation along the lines of Queensland but it did not proceed. Another more draconian private member's Bill, prohibiting entry outright, was introduced in $1880 .{ }^{79}$ It was recognised that the measure might not be assented to because of British treaty considerations. Seddon and Grey both supported the measure, with the latter saying there was no reason why the Bill should not be assented to. The Government had the Bill dropped, however, arguing that it needed to discuss the matter with Australian States to agree upon joint action. The subsequent intercolonial conference agreed that uniform legislation was required to restrict the Chinese influx and that this would be based on Queensland's 1877 poll tax legislation. ${ }^{80}$

In 1881 New Zealand passed the Chinese Immigrants Bill to limit the numbers of Chinese coming into the country. This introduced a $£ 10$ poll tax and a limit of one Chinese person per 10 tons of ship tonnage. Britain assented to this reserved legislation. In 1888 the legislation was amended to restrict entry to one person per 100 tons. The Governor in giving his assent, while noting that objections might be raised against the measure, said that the legislation was similar to that in Victoria to which Britain had assented. ${ }^{81}$ Britain left the Act to its operation.

In 1896 Seddon, himself in the forefront of anti-Chinese agitation, brought in the Asiatic Restriction Bill. This would have repealed the 1881 Act, increased the poll tax to $£ 100$ and prevented people of the "Chinese race" from being naturalised. ${ }^{82} \mathrm{He}$ had considerable difficulty in getting the Bill through Parliament, with stiff resistance in the Legislative Council. The final legislation drew strong protest from a significant minority in the Legislative Council and this protest

77 Swinfen, above n 2, at 144-145; William Pember Reeves, State Experiments in Australia and New Zealand (Macmillan of Australia, Melbourne, 1902) vol 2 at ch 4.

See Todd, above n 2, at 187-196; Keith, above n 2, at Part 5, ch 4.

79 (8 July 1880) 36 NZPD 91-107; (29 July 1880) 36 NZPD 615.

81 (1889) I AJHR A-1 at 2-3 and 9-10. The legislation as passed was only temporary but in 1889 it was made perpetual.

82 (24 July 1896) 93 NZPD 465-472; (1897) I AJHR session II A-1 at 9 and 10; (1896) Journal of the Legislative Council at 98-99; (23 November 1897) 100 NZPD 125. 
was sent to Britain. Seddon nonetheless confidently asserted that as a domestic measure for the country it would not be reserved.

The Governor did reserve the measure. While Seddon awaited Britain's response, he passed the Chinese Immigrants Amendment Bill 1896 as a backstop. This explicitly recognised that the Asiatic Restriction Bill had been reserved and simply raised the poll tax to $£ 100$. This was assented to by the Governor and acted as interim legislation.

Britain withheld assent from the Asiatic Restriction Bill. It suggested new legislation along the lines of the recent South African Natal Act 1897 so the same object was met without being based on colour or race. ${ }^{83}$ Seddon meanwhile attended the Imperial Conference in London in 1897 at which Secretary of State for the Colonies Joseph Chamberlain made it abundantly clear that exclusion on the basis of colour or race was not acceptable. ${ }^{84}$ Only legislation along the lines of the Natal Act would be allowed. Britain did not oppose measures to restrict an influx of immigrants but it must respect the traditions of the Empire.

Seddon temporised, being unwilling to let go of what he saw as a more effective method of restriction of "Asiatics". In 1897 he introduced the Alien Immigration Restriction Bill. Seddon tried to argue that it incorporated some elements of discussion from the Imperial Conference. ${ }^{85}$ The changes were in fact minimal and only related to extended powers of discretionary exemption. The Bill passed the House but was rejected by the Legislative Council. The Governor reported to Britain that the Bill did not meet British expectations and that he would have reserved it had it passed. ${ }^{86}$

In the end Seddon capitulated and brought in legislation modelled on the Natal Act in the Immigration Restriction Bill 1899. This stated in its preamble that, because the 1896 legislation had not been assented to, it was "expedient" to make other provisions. This legislation relied on a concept of British birth and parentage and a language test and did not affect the 1881 Act. It was assented to and became the basis of early 20th century immigration legislation.

\section{TRADE-OFFS}

Trade within the Empire became a prime means of challenging Britain's intervention in legislation on the grounds of imperial interests. Trade became an issue following the recession of the late 1860 s at a time when colonies such as the Australian States and New Zealand wanted to

83 (1898) I AJHR A-1 at 9, and A-2 at 17-20 and 28-29.

84 (1897) I AJHR session II A-4 at 7. For the various Colonial Conferences, 1887-1907, see Maurice Ollivier (ed) The Colonial and Imperial Conferences from 1887 to 1937 (E Cloutier, Queen's Printer, Ottawa, 1954).

85 (3 December 1897) 100 NZPD 307.

86 (1898) I AJHR A-1 at 12-13. 
expand markets. ${ }^{87}$ One way of fostering trade was to agree to reciprocal reductions in customs duties.

\section{A Reciprocity with Australia}

Britain had already lost the battle to prevent Canada passing legislation for reciprocal trade treaties with the United States of America, but wanted to prevent similar developments in the antipodes to preserve its fundamental longstanding policy of free trade and prohibition of differential tariffs. In 1869 New Zealand and the Australian States discussed such issues at a conference. Colonial Treasurer Vogel wanted New Zealand to be able to forge agreements with other countries - Australia and the United States of America - with reduced tariffs or no duty, as Canada had done. He believed that New Zealand was free to do this, although the Attorney-General was less certain.

In 1870 New Zealand passed a Colonial Reciprocity Bill, copied from the Canadian legislation, that allowed for favourable reciprocal duties with Australian States. The Governor reserved the Bill and Britain withheld assent from it. ${ }^{88}$ Britain, while considering the issue of reciprocal favourable tariffs, wanted its free trade policy continued with. The proposed measures amounted to protection in its view. Protectionist tariffs would greatly weaken the ties between the mother country and its colonies.

New Zealand and the Australian States got together in conference in 1871. The Australian States were extremely vocal about their right to advance such policies. New Zealand also strongly disputed Britain's opposition and pressed for intercolonial preference and the right to give differential terms to countries outside the Empire. ${ }^{89}$

Eventually Britain agreed to preferential agreements after a further Australasian conference in 1873. The (Imperial) Australian Colonies Duties Act 1873 allowed Australian States to legislate to provide for preferential duties amongst themselves and with New Zealand, but it prohibited differential duties with other countries and when inconsistent with treaties. New Zealand soon investigated such agreements with Australia, but found that it would lose much revenue and damage local manufacturing, and the matter was dropped. ${ }^{90}$

87 Dalziel Julius Vogel, above n 69, at 100-102 and 132-137; JRM Butler "Imperial Questions in British Politics, 1868-1880" in Benians, above n 36, at 32-33; EA Benians "Finance, Trade and Communications, 1870-1895" in Benians, above n 36, at 184-185 and 220-222; (1869) I AJHR A-6; (1870) I AJHR A-14, for the Australasian conference dealing with trade and tariffs.

88 (1871) I AJHR A-1 at 48; (1872) I AJHR A-1 at 27-31; A-1 A at 47ff; (1873) I AJHR A-3; Hight and Bamford, above n 2, at 387-388; Keith, above n 2, at 930-934; Aikman above n 2, at 12 and 14.

89 (1872) I AJHR A-1 at 27-31; (1873) I AJHR A-3; (1872) GBPP 42 C576 at 55-60.

90 (1875) I AJHR A-6. 
Trade issues reappeared at the first Colonial Conference of 1887 in London. New Zealand pressed the matter of having a role in trade negotiations with foreign powers with an eye to selling frozen meat in France. ${ }^{91}$ The traditional position - with the exception of Canada - was that Britain would always represent its colonies.

The matter arose again at the second Colonial Conference in Ottawa in 1894 at which it was resolved that British legislation should be enacted to enable colonies to agree to reciprocal arrangements and enter into differential tariffs with one another and with Britain. ${ }^{92}$ This was dependent upon Britain denouncing existing trade treaties - a matter it was not prepared to do at that point. Nonetheless, in a first step Britain, through the Australian Colonies Duties Act 1895, removed its prohibition on Australian differential duties. ${ }^{93}$ In the same year New Zealand revised its tariffs, strengthening protection of local industry.

\section{B Imperial Federation?}

The issue became tied up with the matter of imperial federation, pushed by Joseph Chamberlain at the 1897 Colonial Conference in London. ${ }^{94}$ Imperial federation and the reorganisation of imperial trade was seen as a means of strengthening the Empire. Seddon accepted the idea of an imperial council but most colonies feared that federation might encroach on their existing autonomy. At the 1902 Colonial Conference, Seddon proposed that Britain and New Zealand establish a system of preferential tariffs. The conference endorsed the principle of preferential trade within the Empire but Britain had to stand aside because of its continued commitment to free trade.

New Zealand began to open up the issue of preference within the Empire. When New Zealand introduced the Preferential and Reciprocal Trade Bill in 1903, providing for differential tariffs, the Governor refrained from reserving the Bill only because the Government argued that it was an urgent tariff measure. ${ }^{95}$ The Government argued that the country might otherwise be "flooded with

91 (1887) GBPP 56 C5091 475-483; Dalziel The Origins of NZ Diplomacy, above n 50, at 126-127 and 162 164.

92 (1896) I AJHR A-2. New Zealand also raised the matter of whether Governors had to follow ministerial advice on the dissolution of governments. Others at the conference wanted the Governor's independent role to continue.

93 This involved repealing provisions in Australian Constitutions Act 1850 (UK) and in the Australian Colonies Duties Act 1873. See Hight and Bamford, above n 2, at 387-388; JB Condliffe New Zealand in the Making (Allen and Unwin, London, 1959) at 197-198.

94 See Keith Sinclair Imperial Federation: A Study of New Zealand Policy and Opinion 1880-1914 (Athlone Press, London, 1955); RM Burdon King Dick: A Biography of Richard John Seddon (Whitcombe and Tombs Ltd, Christchurch, 1955) at 202-204 and 250-251. For the impact of the free trade and imperial preference debate on colonies, see Richard Jebb Studies in Colonial Nationalism (Edward Arnold, London, 1905).

95 (1903) I AJHR A-1 at 6. 
foreign goods". Seddon made an impassioned plea that the measure was vital for the welfare of the Empire; it had been brought back from the 1902 conference. ${ }^{96}$ The Governor agreed to assent but he wanted Britain to look at the legislation closely. Britain left the Act to its operation. As a result New Zealand subsequently gave Britain preference in its tariff and made preferential treaties with Canada and South Africa.

The Governor was in the same position over the New Zealand and South African Customs Duties Reciprocity Bill in $1906 .{ }^{97} \mathrm{He}$ had wanted to reserve it but the Government argued that it was urgent, in the event of agreeing to a reciprocal treaty before the next session, and he assented to it. Britain again decided to leave the Act to its operation.

There was much discussion of preferential trade at the seminal Colonial Conference in 1907 at which the colonial governments were for the first time treated equally with the British government. Ward also wanted uniformity of practice in the reservation of Bills and the Governor's instructions to be liberalised. New Zealand should have the right to make preferential tariff agreements unfettered by treaties or conventions. ${ }^{98}$ By now a number of preferential agreements were being negotiated, including those mentioned above by New Zealand. Ward argued strongly for imperial preference, suggesting that there was a distinction between this and protection. ${ }^{99}$ The conference once more endorsed the principle of preference within the Empire, with Britain again having to register its inability to adopt preferential tariffs.

With the granting of "Dominion" status for New Zealand following the conference, the need to reserve a wide range of legislation was removed. The instructions of 1892 were revoked in November 1907.100 The Governor no longer had to consider various specific grounds for repugnancy. Powers of reservation were only mentioned in passing - a new clause simply specified the process whereby Bills were assented to or reserved. The Evening Post noted that in future only a few Bills with imperial significance would have to be reserved. ${ }^{101}$

The Attorney-General, Sir John Findlay, remarked that the Governor was no longer bound to require Bills to be reserved (apart from those concerning shipping) but in practice he still exercised discretion over the matter. Regarding it from the point of view of constitutional law, he concluded that "[w]e are masters in our own household only so long as our master permits us to be", even as

\footnotetext{
6 (18 November 1903) 127 NZPD $715 \mathrm{ff}$.

97 (1907) I AJHR A-1 at 7, and A-2 at 8.

98 (1906) I AJHR session II A-4B; (1907) I AJHR A-1 at 6-7.

99 (1907) I AJHR A-5.

100 "Secretary of State for Colonies, Letters Patent for Governor, 18 November 1907" (11 June 1908) New Zealand Gazette at 1639-1641.

101 Evening Post (Wellington, 30 June 1908).
} 
New Zealand gained Dominion status. ${ }^{102}$ The constitutional situation was entirely anachronistic. If Britain desired it could legislate to override any New Zealand legislation. It could even revoke New Zealand's powers of self-government or cede the country to a foreign power. Findlay wanted the constitutional position brought into harmony with New Zealand's Dominion status and Britain's declared "galaxy of free nations".

Nonetheless, New Zealand from this point was free to develop its own tariff policy. ${ }^{103}$ The Preferential and Reciprocal Trade Act 1903 was repealed by the Tariff Act 1907, through which New Zealand thoroughly revised its tariff schedules to the end of imperial preference. The extent of British preference was greatly enlarged over time.

In our discussion we have now reached that benchmark of Dominion status in 1907. While celebrated at the time, historians have found little beyond the symbolic moment itself to draw from the occasion. New Zealand seems to have slipped effortlessly into a more independent role that was to be fully realised in 1947 with the adoption of the Statute of Westminster 1931. In actual fact there was, as discussed, a significant development in the change to the Governor's instructions. We now turn to the enduring problem of shipping legislation. This was an important ingredient in the Colonial Conference of 1907 that yielded Dominion status.

\section{SHIPPING OUT THE PROBLEM}

The denouement to the saga of Britain's role in legislation came with shipping laws. The difficulty involved in regulating merchant shipping in the British Empire, that became a central issue in the mid 1890s, played an important part in New Zealand gaining Dominion status in 1907 and in New Zealand's eventual complete legislative autonomy with its adoption of the Statute of Westminster 1931 in 1947.

\section{A Coasting Along}

Shipping legislation had long been problematic but through much of the 19th century New Zealand acquiesced in amending its legislation as required by Britain. ${ }^{104}$ The imperial Merchant Shipping Act 1854 allowed colonies to repeal provisions of the Act for ships registered within the colony but also required any such legislation to be reserved for confirmation by Her Majesty in Council. Britain could threaten disallowance of offending legislation, as occurred in the case of the Foreign Seamen's Act 1858 (see above).

102 JG Findlay The Imperial Conference of 1911 from Within (Constable, London, 1911) at 65-84, especially at 78.

103 (27 June 1907) 139 NZPD 2 and 4.

104 Keith, above n 2, at 942-949; (29 November 1909) 148 NZPD 454ff. 
Into the $1860 \mathrm{~s}$, as steam was adopted and as New Zealand began to develop its own shipping fleet, colonial legislation became an issue. New Zealand soon realised that Britain would look at such legislation with a fine toothcomb. The Steam Navigation Bill of 1862 was assented to but some issues were noted for amendment by future legislation. The Marine Board Bill of the same year was more problematic. It required immediate amendment because of its provisions for registration of vessels and compulsory pilotage. ${ }^{105}$ New Zealand dealt with these concerns with the Marine Board Act 1863. Britain remained concerned at the pilot provisions, however, as evident in its responses to the Marine Board Act Amendment Bill of 1865 and the Marine Bills of 1866 and $1867 .{ }^{106}$ Britain also required the Steam Navigation Bill 1866 to be amended before assent was given. The amended legislation of 1867 was assented to.

The imperial Merchant Shipping (Colonial) Act 1869 helped clarify matters. It allowed colonies to regulate the coastal trade provided that a reservation clause was in the legislation. But this meant that a long list of New Zealand laws, with the last being enacted in 1946, had to be reserved.

\section{B Shipping Conferences}

The imperial Merchant Shipping Act was re-enacted in 1894. Following this, New Zealand's shipping laws embarked on a period of difficulty. The Shipping and Seamen's Act 1896 (assented to by the Governor) fell foul of the Act. Britain required its amendment to limit its application to coastal shipping. ${ }^{107}$ Premier Seddon was outraged that some British interests wanted the Act disallowed outright. He argued that New Zealand was within its "constitutional rights" to pass such legislation. He pointedly suggested that at least marriage to a deceased wife's sister was legal in New Zealand whereas in England such people would be living in adultery! (This referred to the New Zealand legislation of 1880 discussed above.)

Britain eventually gave way on the understanding that there would be discussions concerning administration of the Merchant Shipping Act. Meanwhile at an Australasian conference in Hobart in 1897 the various Premiers, including Seddon (who was undoubtedly smarting over his rebuffed antiChinese measure), agreed that they should recommend that Britain enact legislation to give the colonial Parliaments greater powers of legislation without reservation. ${ }^{108}$

105 (1863) AJHR A-1 at 26-27; (1864) AJHR A-1 at 16; (1866) AJHR A-1 at 2-3; (1867) AJHR A-1 at 44; (1868) AJHR A-1A at 24-32; (3 November 1863) 1861-1863 NZPD 767.

106 (1867) AJHR A-1 at 47-9; (1868) AJHR A-1 at 5, and A-1 A at 24-32.

107 (1898) I AJHR A-1, at 11-12, and A-2 at 3 and 15-17; (1899) I AJHR A-2 at 25-27.

108 (1897) I AJHR session II A-5. 
Matters came to a head following the Shipping and Seamen Bill of 1903 (which repealed the legislation of 1896). ${ }^{109}$ This was grudgingly assented to in 1905, just within the two year maximum period and after a great deal of doubt as to which kinds of colonial provisions were repugnant.

These matters were addressed at an imperial conference on merchant shipping legislation in 1907. ${ }^{110}$ This focused on New Zealand's 1903 Act and attempted to produce greater uniformity in such legislation. New Zealand agreed to amend the Act. New Zealand, led by William Belcher (head of the Seamen's Union), pushed strongly for the exclusion of coloured labour but Britain rejected this, on the same basis as it had opposed Seddon's 1896 immigration legislation.

New Zealand did indeed amend the 1903 Act in 1909. Despite this it ran into problems. The Bill was assented to only on condition that the legislation was further amended. Sections of the Act had to be amended by the Shipping and Seamen Amendment Act 1911. ${ }^{111}$

New Zealand went ahead in legislating to exclude coloured labour on its ships with the Shipping and Seamen Amendment Bill of 1910. This was an attempt to prevent employment of "Asiatics" through penal levies and was not confined to coastal shipping. The provision, in similar fashion to the Asiatic Restriction Bill 1896, discriminated against British Indian subjects and those of friendly Asian powers. The Government knew full well how controversial the measure would be. Although it had passed through Parliament the legislation was sent to Britain as it stood at its first and second readings. Britain said it would withhold assent until the matter of Dominion legislative powers had been discussed at the Imperial Conference in 1911. ${ }^{112}$ Meanwhile Britain said that it would adhere to the resolution agreed to at the shipping conference of 1907 - colonial conditions would apply to vessels registered in the colony and others involved in coastal trading. ${ }^{113}$

New Zealand was keen to make progress on such issues at the 1911 conference. Prime Minister Ward was very unhappy at the delays in getting assent and stated that New Zealand was much better able to judge what laws suited it than was Britain. Ward pushed the Shipping and Seamen Amendment Bill of 1910 strongly - the employment of "Asiatics" was a menace threatening the livelihood of New Zealand seamen - but to no avail. Britain continued to withhold assent from the Bill and it never got onto the statute book.

109 (1905) I AJHR A-1 A; (1906) I AJHR session II A-4B; (1907) I AJHR A-1 at 6-7.

110 (1907) I AJHR A-5A at 108-116.

111 (1911) I AJHR A-1 at 36; A-2 at 11, 64-66 and 82. The Harbours Amendment Act 1908 was also seen as problematic for not conforming to the Merchant Shipping Act 1894. Britain was not going to disallow it but asked New Zealand to amend it. This was done in 1910, see (1910) I AJHR A-1 at 11, and A-2 at 10 and 11.

112 (1911) I AJHR A-1 at 19, and A-2 at 67-68.

113 (1911) I AJHR A-1 at 13. 
Ward wanted greater uniformity in various laws that in the past had to be reserved and Dominions to be given wider legislative powers regarding shipping. ${ }^{114} \mathrm{He}$ got into an argument with the Australian delegation over the extent to which Governors had real reserve powers, and when he insisted on a vote on wider legislative powers only Canada supported him. Australia, South Africa, Newfoundland and Britain abstained. The debate was revealing. The issue had largely become a semantic one - whether the country believed the Governor had such powers. Australia chose to believe that he did not. New Zealand argued that it was still constrained, as evident in the 1910 legislation.

\section{The New Shipping Order}

Despite these contretemps the reality was that New Zealand was gaining more autonomy in its legislating in the wake of becoming a Dominion. While shipping legislation still had to be confirmed by Britain, the 1903 Act remained the basis of New Zealand's shipping laws. The amending shipping legislation of 1912, 1913, 1922, 1924, 1925 and 1929 was reserved and assented to by Britain without difficulty.

Following the First World War, New Zealand and other Dominions gained in autonomy. The Imperial Conference of 1926 defined the new relationship between Britain and its Dominions. ${ }^{115}$ It was agreed that the Dominions were autonomous and equal in status to Britain and not subordinate. Aside from provisions in constitutions or in statutes providing for reservation of Bills, a Dominion had the right to advise Britain "in all matters relating to its own affairs". ${ }^{116}$ With regard to the legislative competence of Dominions, and specifically in relation to extra-territoriality, British legislation applying to a Dominion would only be passed with its consent. However, the conference conceded that it could not deal adequately with the complex issues associated with powers of assent and this was left to a committee to consider further.

In the end these issues were resolved at a shipping legislation conference in 1929. ${ }^{117}$ This conference removed important impediments and opened the way for Britain to pass the Statute of Westminster in 1931. The conference agreed that disallowance could no longer be exercised over Dominion legislation. Dominions could change their constitutions to abolish disallowance if they wished. The conference also recommended that the discretionary reservation power of GovernorsGeneral be abandoned. Where reservation powers existed by statute, such as in constitutional legislation, the advice of a British government to the Crown should not run counter to the views of a

\footnotetext{
114 (1910) I AJHR A-4; (1911) I AJHR A-4 at 394-405

115 (1927) I AJHR A-6 at 8-12.

116 (1927) I AJHR A-6 at 11.

117 (1930) I AJHR A-6 at 5-14.
} 
Dominion when the Dominion's own affairs were involved. Dominions should also be able to amend their constitutions so that reservation was no longer required.

The conference observed that the extra-territorial operation of Dominion legislation was a confused area and that it was not possible to come to a definite conclusion about the competence of Dominion legislation. The uncertainty meant that Britain should legislate to make it clear that a constitutional limitation no longer existed. This required the repeal of the Colonial Laws Validity Act 1865 as it related to Dominion laws. The conference recommended that it should be understood as a constitutional convention that no British law should extend to a Dominion without its request and consent. These changes would give Dominions full legislative powers.

Britain shortly thereafter passed the Statute of Westminster 1931. This gave Dominions, when they chose to adopt the Statute, full powers of extraterritorial legislation and protected them again repugnancy and the extension of British law to their country without their "request and consent". The Colonial Laws Validity Act 1865 would no longer apply to legislation.

But with New Zealand choosing not to adopt the Statute of Westminster for some time, shipping legislation still had to be reserved. This occurred in 1935, 1936, 1940 and 1946. Finally in 1947, after the extra-territorial difficulties experienced during the Second World War and with the example of Australia before it, New Zealand adopted the Statute of Westminster. The assent provisions of the Constitution Act 1852 remained in place but the long process of New Zealand gaining autonomy from Britain had taken another substantial step. Bills were no longer reserved and Britain no longer intervened in New Zealand's lawmaking in the way it had done in the past. New Zealand was free of the constraints of repugnancy and the extra-territorial effect of legislation.

\section{CONCLUSION}

This review of New Zealand legislation indicates the extent to which New Zealand's lawmaking was enmeshed with Britain over a long period of its history. Some thirteen laws were sufficiently problematic that Britain either disallowed them, refused assent to them or withheld assent from them. Others had to be amended on Britain's instructions. Britain had a role in a wide range of legislation which was central to the governing of the colony - from the selling of land to the relationship of the provinces to the central government, laws relating to the land wars of the early $1860 \mathrm{~s}$, trade, imperial aspirations, immigration, and the regulation of merchant shipping.

By the end of the 19th century, New Zealand was less willing to accept such constraints on its legislative activity, but it still took a long time before New Zealand gained full legislative powers. The Governor's instructions were altered in 1892 and 1907, reducing his powers of reservation of legislation. This was associated with New Zealand attaining Dominion status, which was more than simply a symbolic statement. As a Dominion, New Zealand subsequently had protracted discussions over shipping legislation, associated with the passing of the Statute of Westminster in 1931 and its eventual adoption by New Zealand in 1947. 
Britain would use its powers to assent to New Zealand legislation in a variety of circumstances, on occasion bizarre as a result of New Zealand's politics. Governments could encourage the Governor to refuse assent, as occurred in 1861 and in 1877. Bills could be used as levers to extract legislation out of Britain and conflicts within Parliament could be expressed in problematic laws. Such episodes are part of the colourful history of lawmaking in New Zealand.

But more than this, the exercise of royal assent was part of an enduring and important relationship between Britain and New Zealand which needs to be recognised. This power was an important ingredient in the development of the colony and a vital element in understanding how New Zealand arrived at its present constitutional state. Without this, the story of the movement from colony to independent nation is incomplete and somewhat inexplicable. The change was a lengthy and a gradual process, and British vetting of New Zealand lawmaking was an integral part of this process. 